\title{
$U R-261$
}

STUDIES ON FLASH BURTS: THE PROTECTION AFFORDED BY 2,4 AND 6 IAYER FABRIC COMBIIATIONS by :

George Mixtier and Herman E. Pearse

THE UNIVERSITY OF ROCHESTER ATOMIC ENERGY PROJECT ROCHESTER, NEW YORK 


\section{DISCLAIMER}

This report was prepared as an account of work sponsored by an agency of the United States Government. Neither the United States Government nor any agency Thereof, nor any of their employees, makes any warranty, express or implied, or assumes any legal liability or responsibility for the accuracy, completeness, or usefulness of any information, apparatus, product, or process disclosed, or represents that its use would not infringe privately owned rights. Reference herein to any specific commercial product, process, or service by trade name, trademark, manufacturer, or otherwise does not necessarily constitute or imply its endorsement, recommendation, or favoring by the United States Government or any agency thereof. The views and opinions of authors expressed herein do not necessarily state or reflect those of the United States Government or any agency thereof. 


\section{DISCLAIMER}

Portions of this document may be illegible in electronic image products. Images are produced from the best available original document. 


\title{
1 -
}

UNCIASSIFIED

\section{URm261}

Health and Blology

\author{
THE UNIVERSITY OF ROCHESTHER \\ Atomic Inergy Project \\ P. 0.- Box 287, Station 3 \\ Rochester 20 , New York \\ Contract $W-7401$ weng 49 \\ ***
}

STUDIES ON FIASH BURIVS: THE PROTECTION

AFHORDED BY 2,4 AND 6 IAYER FABRIC COMBIINATIONS

by:

Goorge Mixter and Herman E. Pearse

Division: Special Programe

Section: Flash Burn
Division Head: Ho A。 Blair

Section Head: Ho Do Kingaley

Submitted by: Henry A。 Blair,

Date of Report: $6 / 4 / 53$ Director

UNCLASSIFIED 
TABLE OF CONPENTS

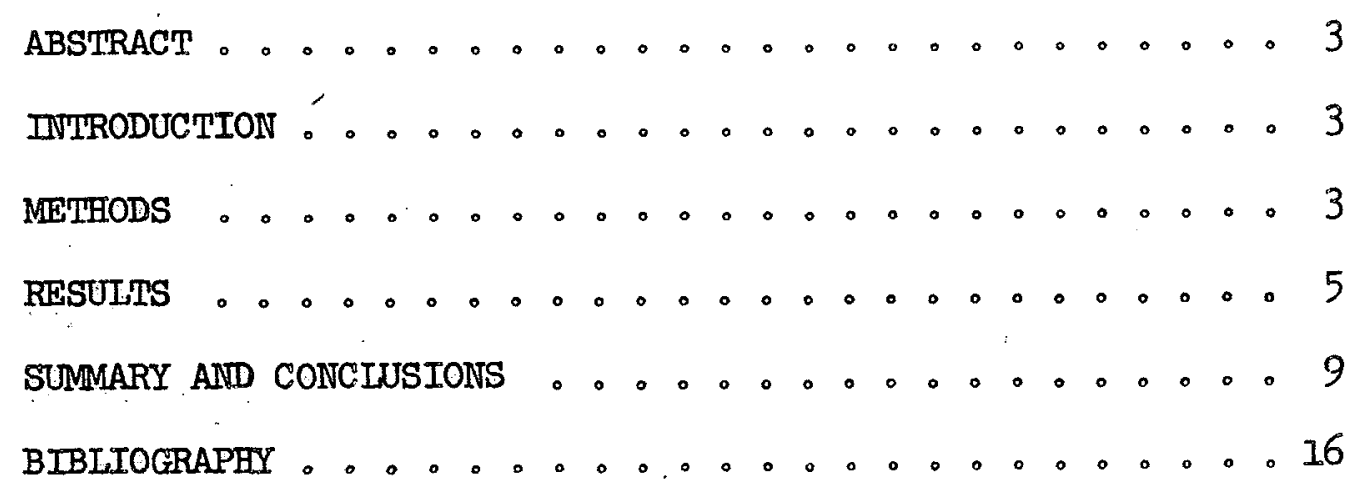


STUDIES ON FLASH BURNS:

THE PROTECTION AFFORDED BY 2,4 AND 6 IAYYER FABRIC COMBINATIONS

by

George Mixter, Jr。, M。D。 and Herman E。 Pearse, M。D。

\section{ABSTRACT}

Fabric interposed between a carbon are source and the skin of Chester White pigs increased the amount of thermal energy required to cause $2+$ burns. For the 2, 4 and 6 layers of fabric studied this increase was $3.6,38$ and over $104 \mathrm{cal} / \mathrm{cm}^{2}$ respectively when the inner layer of fabric was in contact with the skin. Separation of the inner layer from the skin by $5 \mathrm{~mm}$ increased the protective effect of the 2 layer combination from 7.4 to $29 \mathrm{cal} / \mathrm{cm}^{2}$, provided the outer layer was treated for fire retardation. If the outer layer was not so treated, sustained flaming occurred which in itself added to the thermal burn. $(\ldots \ldots)$.

\section{INTRODUCTION}

In the past, work in this laboratory has been directed toward a study of flash burns in unshielded skin.. It is well known from the atomic bombing in Japan that this type of burn was modified by elothing. A laboratory analysis of the protective effect of fabrics against flash burns was begun (5) by shielding the skin with a few representative fabrics and their combinations. The experiments here reported are a continuation of this type of study using 2,4 and 6 layers of material such as might be worm under hot, temperate or cold conditions.

\section{METHODS}

Young Chester White pigs anesthetized with intraperitoneal dialurethane $(65$ to $70 \mathrm{mg} / \mathrm{kg})$ (2) were used. The radiant energy source was a 24-inch carbon arc searchlight with an elliptical mirror and other modifications 
as previously described (1). The focal area or port employed was circular, with a diameter of $1.7 \mathrm{~cm}$. Fabric samples were attached over the back of the port in the "transite" shield, and the animal then held firmly in apposition. For the "spacing" experiments, a polished aluminum ring with a central aperture of $1.7 \mathrm{~cm}$ was secured between the fabric and the skin; its thickness of. $5 \mathrm{~mm}$ thus determined the airspace between fabric and skin. The pigs were hosed off and allowed to dry. After anesthesia was established, the hair was removed as closely as possible with an electric clipper and the skin gently wiped with a damp cloth. No other skin preparation was employed. The required exposures were distributed in a random fashion among twenty-one positions ( 3 rows of 7 burns each) on either side of the pig. In this way two purposes were accomplished: avoidance of bias by the observer, who had no knowledge of the radiant exposure used to produce any given burn; and equitable aivision of all exposures between the potentially more or less sensitive areas of the pig.

Burns were inspected immediately and at 24 hours. At the latter time the gross appearance of the burn was noted for purposes of evaluation, and repreantative burns of various degrees were biopsied.

The fabric combinations used are listed below, in order from without inward. For the flame-resistant fabric studies, the outer layer of the system was made up of cloth which had been impregnated with "HPM", a plastic polymer, whereby its weight was increased by approximately 25 per cent. AlI samples exposed were labeled and preserved for later evaluation.

\section{2 Layers}

a. Iight green oxford knitted cotton underwear

b. light green oxford (HPM) knitted cotton underwear 


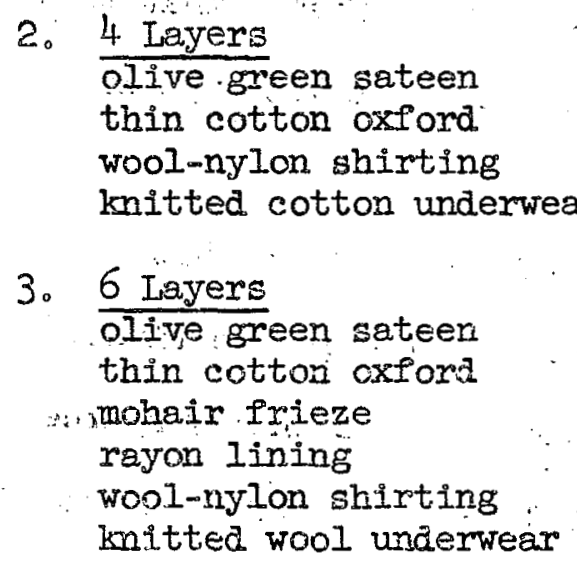

\section{RESULTS}

Both grossly and microscopically, the burns resulting from exposures under fabric differ somewhat from the flash burn as described in previous reports from this laboratory $(4,6)$. Staining of the skin with tar obscures that delicate cloualness of the epidermis, which is the earliest indication of a $2+$ burn. The exythema observed is in general more intense, and has a more cyanotic or brownish hue, than burns of comparable degree on bare skin. This erythema does not blanch on pressure. Microscopically, allation of capillaxies is prominent, many of the venules appear packed and lysis of the cells is noticeable. Rough estimation of hair follicle damage indicates. that for a given degree of surface damage, the depth of damage appears to be greater than in true "flash" burns.

These effects are comparable to the results from a longer exposure (6) and lower intensity of thermal trauma.

As to correlation between gross and microscopic appearances of the lesion, it appears that the burn produced under fabric shows a correspondence, roughly similar to that of the standard flash burn; epidermal necrosis is present in spotty areas even in the "1+mild" group; and in those classified as "I+ severe", sections show that epidermal necrosis is complete. The one microscopic feature that is common to the $2+$ minimal burns is a 
separation of the dermal-epidermal interface, and it is probable that this structural change is actually responsible for the pearly opalescence of the skin which forms the criterion for a $2+$ burn.

Table 1 presents the data accumulated on 6 layers. Note that it was not possible to cover the necessary range with short exposure times. The practical upper limit of irradiance obtainable with the energy source employed was $37.5 \mathrm{cal} / \mathrm{cm}^{2} / \mathrm{sec}$. In the case of 6 layers of fabric it was necessary to use an exposure of $3.0 \mathrm{sec}$ to obtain the mildest burns. Even with the greatest energy used against 6 layers $\left(108 \mathrm{cal} / \mathrm{cm}^{2}\right)$ only two of the 4 exposures resulted in a minimal burn of the skin (mild erythema). Even at this high level of energy there was no discernable sustained flaming of the fabric. A hole was produced successively through the outer layers leaving the irmer ones intact. It was felt that no useful information would be gained by detailed studies at energy levels of this magnitude, so no attempt was made to define thresholds of $2+$ burns under six layers. When the skin was in contact with the inner layer of a four fabric system, $2+$ burns began to sccur with significant frequency at $40 \mathrm{cal} / \mathrm{cm}^{2}$, and the majority of our observations were concentrated about this level in order to define with accuracy the critical energy necessary to produce a burn on the pig which would be comparable to a second-degree burn in the human. The results are shown in Table 2 where it is seen that in 164 experiments the 4 layers gave absolute protection from $36 \mathrm{cal} / \mathrm{cm}^{2}$ delivered in 1 sec. A significant number of $2+$ burns occurred with $40 \mathrm{cal} / \mathrm{cm}^{2}$ and continued through the range to $60 \mathrm{cal} / \mathrm{cm}^{2}$ where the first $3+$ burn occurred. A graph of these data is presented in Figure 1 , in which are plotted the percentage of exposures resulting in a $2+$ burn at the various levels of energy used. At $44 \mathrm{cal} / \mathrm{cm}^{2}$, half the observed exposures resulted in a $2+$ burm or more; this amount of energy can then be said to be the "50\% 
effectiverdose"!, or $E_{50}(7)$

The data on the : 2 layer system (regular) in which the outer layer was not treated for fire retardation is given in Table $3 \mathrm{a}$. That in which the outer layyertwas treated with a fire retardant (HPM) is given in Table 3b. In testing both of these combinations the inner layer was in contact with the piglis skin: The results are shown graphically in Figure 2 where it is seenthat there isopractically no difference in the protective effect between a flame proofed and an untreated outer layer, so long as the Inner layer is ins contsctiwith the skin. The 50 for 2+ burns of unprotected pig skin createditiths 0.5 sec exposures is about $3.8 \mathrm{cal} / \mathrm{cm}^{2}$. The $\mathrm{ED}_{50}$ under the untreatedra layer combination is $7.3 \mathrm{cal} / \mathrm{cm}^{2}$ and for that having thel outer layer flame proofed with HPM is $7.4 \mathrm{cal} / \mathrm{cm}^{2}$. Thus, under the conditions of this experimentronly 3.6."ealories of protection" were given by these 2 layers of fabric

When the interposed fabric system is separated from the skin by some finite air space, there is an alteration in the character and intensity of the thermal energy transferred to the skin. Also under these conditions: an aditionaluthermal:component was at times observed; the fiabric sometimes caught efire; fand this exothermic reaction persisted after cessation of the ratiant exposire $\mathrm{A}$ mirror was therefore placed in back of the shutter so that the outer fabric layer could be observed ; and the persistence of flaming conlar be âcurately "timed, vas "well as the tred "afterglow". that . frequentiy oceurised the partially destroyed fabricio:

In Tabie $4 a$ the results of such an experiment are presented. In this casetthe 2 layer fabric system (without fire-retardant) was separated from the skin by a 5 malrspace. It will be noted that significant numbersof severe" burns" began to appéar above $7 \mathrm{cal} / \mathrm{cm}^{2}$, reached a peak at $9 \mathrm{cal} / \mathrm{cm}^{2}$, and then began to drop off, until at $15 \mathrm{cal} / \mathrm{cm}^{2}$ no exposure 
resulted in a burn of even $1+$ mild degree. At this level of exposure, the outer cloth layer was Invarlably "punched out" cleanly at the end of the exposure perlod; and the inner, knitted layer failed to ignite:

Above this level, the Inner layer caught fre; above $24 \mathrm{cal} / \mathrm{cm}$, both layers were destroyed during exposure, ind there remained no material either to support combustion or to protect the skin. Fig. 3 shows the correlation between the average duration of flame ter exposure and the percentage of $2+$ burns at each energy-level:

Two other observations of a supplementary náture should also be.s recorded. Direct inspection of fábrics in the beam of the arc shows that as the material disintegrates, a puff of vapor escapes from the surface, and at irradiances of over $20 \mathrm{cal} / \mathrm{cm}^{2} / \mathrm{sec}^{\text {this }}$ cloud .ignites almost immediately. in an lntensely hot flare away from the charring surface. The inner layer of fabric, and usually the skin itself, are more or less deeply stained with. a brownish, tarry deposit, indicating that the products of the destructive distillation of the fabric constitute $a$ definite mechanism of thermal transfer.

When the experiment was repeated with the outer layer of flameretardant cloth and the inner layer 5 um from the skin, no instances of flaming occurred below $20 \mathrm{cal} / \mathrm{cm}^{2}$, although above this level there was in many cases a weak, ghostly flame which persisted only for a few seconds. Failure of this fabric to sustain combustion after the exposure period eliminated the group of burns previously observed at exposures of 8 to 15 $\mathrm{cal} / \mathrm{cm}^{2}$.

"As will be seen in Table $4 \mathrm{~b}, 2+$ burns do not appear until $26 \mathrm{cal} / \mathrm{cm}^{2}$ is reached; the $\mathrm{ED}_{50}$ occurs at $29 \mathrm{cal} / \mathrm{cm}^{2}$. Note, however, that burns at the erythema level: were occurring throughout the entire range from 9 to 29 $\mathrm{cal} / \mathrm{cm}^{2}:$ 


\section{9.}

A graphic comparison between the treated cloth (HPM) and the untreated, under these circumstances, is shown in Fig. 4\%. Here the percentage of $2+$ burns sustained at the various levels is plotted against the radiant exposure given. Contrast the marked benefit from fire-retardant treatment seen here with the virtual absence of such benefit when the cloth samples were in contact with skin (Fig。2)。

The data presented above have been subjected to a simplified probit analysis as described" by 'itchfield and Wilcoxon (5), and the "confidence intervals" calculated."Within these limits 95 per cent of observations may be expected to yield the stated result. Table 5 presents these limits, together with the "ED 50 as given" by the same analysis, and the lengths of exposures used:

\section{SUMMARY AND CONCLUSIONS}

1) Previous studies in this laboratory on the protective effect of fabrics against flash burns have been extended to observe the results in 6,4 and 2 layer fabric combinations such as would be worn in cold, temperate and hot weather.

$$
\text { thes a }
$$

2) In clinical practice $2^{\circ}$ burns are usually incapacitating so a minimal $2+$ burn was used as the critical damage level in this study. The $50 \%$ probability threshold for this degree of injury was then used to determine the "calories of protection" given by a fabric combination.

3) The gross and microscopic appearance of burns sustained through fabrics resembles that seen on unprotected skin after longer exposures to a lower

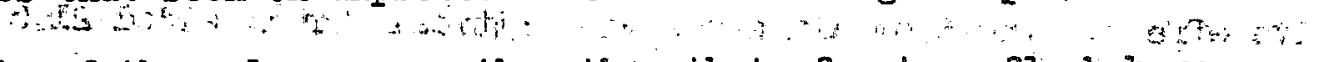
intensity of thermal energy rather than that of a true flash burn. 4) When 6 layers of fabric (for winter wear) were placed over pigis skin it required $108 \mathrm{cal} / \mathrm{cm}^{2}$ from a carbon arc source to cause only mild erythema in half the tests. This level of thermal energy from a nominal atomic bomb 


\section{0}

occurs only within the zone of total destruction where irradiation and blast effects are lethal. Hence it was not considered necessary to do detailed studies at energy levels of this magnitude.

5) Four layers of fabric gave absolute protection up to $36 \mathrm{cal} / \mathrm{cm}^{2}$. In the range from 40 to $60 \mathrm{cal} / \mathrm{cm}^{2}, 2+$ burns aid occur; the ED 50 for this injury was found to be $44 \mathrm{cal} / \mathrm{cm}^{2}$.

6) Two layers of light fabric for sumer wear gave little protection so long as the inner layer was in contact with the skin. Sustained flaming does not ordinarily occur under these circumstances so that flame proofing had little influence. When the outer layer was treated with fire retardant and the inner leyer was in contact with the skin the $\mathrm{ED}_{50}$ for $2+$ burns was $7.4 \mathrm{cal} / \mathrm{cm}^{2}$. It was practically the same $\left(7.3 \mathrm{cal} / \mathrm{cm}^{2}\right)$ when the outer layer was untreated.

7) The separation of the inner layer by $5 \mathrm{~mm}$ from the pigs' skin allowed the 2 layer untreated fabric combination to catch fire after $0.5 \mathrm{sec}$ exposures to irradiances from 14 to $28 \mathrm{cal} / \mathrm{cm}^{2} / \mathrm{sec}$. Associated with such flaming there were severe burns to the pig。 At $15 \mathrm{cal} / \mathrm{cm}^{2}$ exposures, the outer layer was corpletely disintegrated, no flame occurred, and no burms were sustained. Above this level the inner layer caught fire, and $2+$ burns occurred with increasing frequency.

8) Treatment of the outer layer with flame retardant (HPM) prevented flaming when the inner layer was separated $5 \mathrm{~mm}$ from the skin. Under these conditions the $\mathrm{ED}_{50}$ for $2+$ burns was $29 \mathrm{cal} / \mathrm{cm}^{2}$, which is a striking increase in protective effect. The $5 \mathrm{~m}$ air space was critical for it added 21.6 calories of protection over that provided by the same combination when in contact with the skin。 
TABLE 1

BURNS SUSTAINED BY CHESTERR WHITE PIGS THROUGH 6-IAYER FABRIC IN CONTACT WITH SKIV

\begin{tabular}{|c|c|c|c|c|c|}
\hline $\begin{array}{l}\text { Time } \\
\text { (Sec) }\end{array}$ & $\begin{array}{l}\text { Irradiance } \\
\left(\mathrm{cal} / \mathrm{cm}^{2} / \mathrm{sec}\right)\end{array}$ & $\begin{array}{l}\text { Exposure } \\
\left.\text { (cal/cm }{ }^{2}\right)\end{array}$ & $\begin{array}{l}\text { No } \\
\text { Burn }\end{array}$ & It & $2+$ \\
\hline $\begin{array}{l}1 \\
2 \\
2 \\
2 \\
2 \\
2 \\
3\end{array}$ & $\begin{array}{l}18 \\
12 \\
18 \\
24 \\
28 \\
36 \\
36\end{array}$ & $\begin{array}{r}18 \\
24 \\
36 \\
48 \\
56 \\
72 \\
108\end{array}$ & $\begin{array}{l}6 \\
6 \\
6 \\
6 \\
6 \\
6 \\
3\end{array}$ & $\begin{array}{l}0 \\
0 \\
0 \\
0 \\
0 \\
0 \\
3\end{array}$ & $\begin{array}{l}0 \\
0 \\
0 \\
0 \\
0 \\
0 \\
0\end{array}$ \\
\hline
\end{tabular}

TABIE 2

BURNS SUSTATNED BY CHESTER WHTIE PIGS THROUGH 4-IAYER FABRIC IN CONTACT WITH SKIN

\begin{tabular}{|c|c|c|c|c|c|c|c|c|c|}
\hline $\begin{array}{l}\text { Time } \\
\text { (Sec) }\end{array}$ & $\begin{array}{l}\text { Ca.l } \\
\mathrm{cm}^{2} \\
\text { Sec }\end{array}$ & $\begin{array}{l}\mathrm{Cal} / \\
\mathrm{cm}^{2}\end{array}$ & $\begin{array}{l}\text { No } \\
\text { Burn }\end{array}$ & $\begin{array}{c}\text { It } \\
\text { Mild }\end{array}$ & $\begin{array}{l}1+ \\
\text { Sev }\end{array}$ & $\begin{array}{c}2+ \\
\text { Mild }\end{array}$ & $2+\begin{array}{l}\text { Mod } \\
\text { Sev }\end{array}$ & $3+$ & Total \\
\hline 0.5 & $\begin{array}{l}24 \\
30 \\
36 \\
\end{array}$ & $\begin{array}{l}12 \\
15 \\
18 \\
\end{array}$ & $\begin{array}{l}1 \\
1 \\
1\end{array}$ & $\begin{array}{l}0 \\
0 \\
0\end{array}$ & & & & & $\begin{array}{l}1 \\
1 \\
1 \\
\end{array}$ \\
\hline 1.0 & $\begin{array}{l}22 \\
24 \\
30 \\
36\end{array}$ & $\begin{array}{l}22 \\
24 \\
30 \\
36\end{array}$ & $\begin{array}{r}1 \\
1 \\
6 \\
15\end{array}$ & $\begin{array}{l}0 \\
0 \\
0 \\
0\end{array}$ & & & & & $\begin{array}{r}1 \\
1 \\
6 \\
15\end{array}$ \\
\hline 2.0 & $\begin{array}{l}15 \\
20 \\
22 \\
24\end{array}$ & $\begin{array}{l}30 \\
40 \\
44 \\
48\end{array}$ & $\begin{array}{l}2 \\
2 \\
0 \\
0\end{array}$ & $\begin{array}{l}2 \\
6 \\
2 \\
1 \\
\end{array}$ & $\begin{array}{l}0 \\
6 \\
5 \\
8\end{array}$ & $\begin{array}{l}1 \\
7 \\
7 \\
9\end{array}$ & $\begin{array}{l}0 \\
1 \\
6 \\
4\end{array}$ & $\begin{array}{l}0 \\
0 \\
0 \\
\end{array}$ & $\begin{array}{r}5 \\
22 \\
20 \\
22 \\
\end{array}$ \\
\hline 1.5 & 35 & 52 & 0 & 1 & 8 & 5 & 3 & 0 & 17 \\
\hline 2.0 & $\begin{array}{l}27 \\
28 \\
30 \\
32\end{array}$ & $\begin{array}{l}54 \\
56 \\
60 \\
64\end{array}$ & 1 & $\begin{array}{l}1 \\
0 \\
:\end{array}$ & $\begin{array}{l}3 \\
2 \\
0\end{array}$ & $\begin{array}{l}4 \\
3 \\
7 \\
0\end{array}$ & $\begin{array}{r}3 \\
12 \\
12 \\
1\end{array}$ & $\begin{array}{l}0 \\
0 \\
1 \\
0\end{array}$ & $\begin{array}{r}12 \\
17 \\
20 \\
1\end{array}$ \\
\hline 1.9 & 35 & 66 & & & & 0 & 1 & 0 & $I$ \\
\hline 2.0 & 36 & 72 & . & & & 0 & 1 & 0 & $\frac{1}{164}$ \\
\hline
\end{tabular}


TABLE $3 a$

BURNS SUSTAINED BY CHESTER WHITE PIGS THROUGH 2 LAYERS (REGULAR) IN CONTACT WITH SKIN

\begin{tabular}{|c|c|c|c|c|c|c|c|c|c|}
\hline \multirow[b]{2}{*}{ Time: } & \multirow[b]{2}{*}{$\mathrm{Cal} / \mathrm{cm}^{2}$} & \multirow[b]{2}{*}{ No Burn } & \multicolumn{2}{|c|}{$1+$} & \multicolumn{3}{|c|}{$2+$} & \multirow[t]{2}{*}{$3+$} & \multirow[t]{2}{*}{$4+$} \\
\hline & & & Mi & $\mathrm{S} \in \mathrm{v}$ & Mi & Mod & Sev & & \\
\hline $\begin{array}{l}0.5 \\
0.5 \\
0.5 \\
0.5 \\
0.5 \\
0.5 \\
0.5 \\
0.5 \\
0.5 \\
0.5\end{array}$ & $\begin{array}{r}4 \\
5 \\
6 \\
7 \\
8 \\
9 \\
10 \\
12 \\
15 \\
18 \\
\end{array}$ & 2 & $\begin{array}{l}2 \\
6 \\
2 \\
1 \\
2\end{array}$ & $\begin{array}{l}1 \\
5 \\
6 \\
3 \\
2 \\
4\end{array}$ & $\begin{array}{r}2 \\
9 \\
12 \\
6 \\
6\end{array}$ & $\begin{array}{l}1 \\
1 \\
2 \\
4 \\
6\end{array}$ & $\begin{array}{l}1 \\
3 \\
7 \\
4\end{array}$ & $\begin{array}{l}3 \\
1 \\
1 \\
1\end{array}$ & \\
\hline $\begin{array}{l}1.0 \\
1.0\end{array}$ & $\begin{array}{l}24 \\
30\end{array}$ & & & & & & & 1. & 1 \\
\hline
\end{tabular}

TABLE 30

BURNS SUSTAINED BY CHESTER WHITE PTGS THROUGH 2 IAYERS (HPM) IN CONTACT WITH SKIN

\begin{tabular}{|l|c|c|c|c|c||c|c|c|c|}
\hline Time & $\mathrm{CaI} / \mathrm{em}^{2}$ & No Burn & $\overline{\mathrm{MI}}$ & $\mathrm{Sev}$ & $\mathrm{MI}$ & $\mathrm{Mod}$ & $\mathrm{Sev}$ & $3+$ \\
\hline 0.5 & 6 & 2 & 9 & 8 & 5 & & & \\
0.5 & 7 & & 4 & 11 & 6 & 3 & & \\
0.5 & 8 & & 2 & 5 & 6 & 7 & 4 & \\
0.5 & 9 & & 1 & 4 & 6 & 7 & 6 & \\
0.5 & 10 & & & 2 & 5 & 6 & 7 & 3 \\
\hline
\end{tabular}


TABIE $4 a$

BURNS SUSTAINED IN CHESTER WHITE PIGS UNDER 2 LAYERS (REGULAR)

SEPARATED FROM SKIN BY 5 MILITIMTLERS

\begin{tabular}{|c|c|c|c|c|c|c|c|c|c|c|}
\hline \multirow{2}{*}{$\begin{array}{l}\text { Time } \\
\text { (See) }\end{array}$} & \multirow{2}{*}{$\begin{array}{l}\mathrm{Cal}_{\mathrm{I}} / \mathrm{J} \\
\mathrm{Cm}^{2}\end{array}$} & \multirow{2}{*}{$\begin{array}{l}\text { No } \\
\text { Burn }\end{array}$} & \multicolumn{2}{|c|}{$1+$} & \multicolumn{3}{|c|}{$2+$} & \multirow[t]{2}{*}{$3+$} & \multirow[t]{2}{*}{$4+$} & \multirow[t]{2}{*}{ Total } \\
\hline & & & $\mathrm{Mi}$ & Sev & Mi: & MOद & Sev & & & \\
\hline $\begin{array}{l}0.5 \\
0.5 \\
0.5 \\
0.5 \\
0.5 \\
0.5 \\
0.5 \\
0.5 \\
0.5 \\
0.5 \\
0.5 \\
0.5\end{array}$ & $\begin{array}{r}6 \\
7 \\
8 \\
9 \\
10 \\
11 \\
12 \\
14 \\
15 \\
16 \\
18\end{array}$ & $\begin{array}{r}4 \\
7 \\
7 \\
3 \\
3 \\
6 \\
6 \\
9 \\
12 \\
9 \\
3\end{array}$ & $\begin{array}{l}1 \\
3 \\
1 \\
3\end{array}$ & $\begin{array}{l}1 \\
1\end{array}$ & $\begin{array}{l}I \\
I \\
I\end{array}$ & $\begin{array}{l}4 \\
1 \\
1\end{array}$ & $\begin{array}{l}1 \\
1 \\
5 \\
2 \\
2 \\
3 \\
1\end{array}$ & $\begin{array}{l}1 \\
1\end{array}$ & & $\begin{array}{r}4 \\
10 \\
10 \\
11 \\
12 \\
12 \\
14 \\
13 \\
12 \\
9 \\
5 \\
\end{array}$ \\
\hline $\begin{array}{l}0.6 \\
0.6 \\
0.6 \\
0.6 \\
0.6\end{array}$ & $\begin{array}{l}14 \\
16 \\
18 \\
20 \\
22\end{array}$ & $\begin{array}{l}5 \\
5 \\
4 \\
3 \\
1 \\
\end{array}$ & $\begin{array}{l}1 \\
5\end{array}$ & $\begin{array}{l}1 \\
1\end{array}$ & 1 & $\begin{array}{l}1 \\
1 \\
1 \\
3 \\
3 \\
\end{array}$ & $\begin{array}{r}3 \\
9 \\
\end{array}$ & $\begin{array}{l}1 \\
1\end{array}$ & & $\begin{array}{r}6 \\
7 \\
7 \\
16 \\
15 \\
\end{array}$ \\
\hline $\begin{array}{l}0.8 \\
0.8 \\
0.8 \\
0.8\end{array}$ & $\begin{array}{l}24 \\
26 \\
28 \\
30\end{array}$ & & & & $\begin{array}{l}2 \\
2 \\
2\end{array}$ & $\begin{array}{l}4 \\
3 \\
1\end{array}$ & $\begin{array}{l}4 \\
4 \\
7 \\
1\end{array}$ & $\begin{array}{l}1 \\
3 \\
4\end{array}$ & 4 & $\begin{array}{l}10 \\
10 \\
10 \\
10\end{array}$ \\
\hline
\end{tabular}


TABIF $4 \mathrm{~b}$

BURNS SUSTAINED IN CHESTTR WHITE PIGS UNDER 2 IAYERS (HFM)

SEPARATED FROM SKIN BY 5 MILITMETTERS

\begin{tabular}{|c|c|c|c|c|c|c|c|c|c|}
\hline \multirow{2}{*}{$\begin{array}{l}\text { rime } \\
\text { (Sec) }\end{array}$} & \multirow{2}{*}{$\begin{array}{l}\mathrm{Cal} / \\
\mathrm{cm}^{2}\end{array}$} & \multirow{2}{*}{$\begin{array}{l}\text { No } \\
\text { Burn }\end{array}$} & \multicolumn{2}{|c|}{$1+$} & \multicolumn{3}{|c|}{$2+$} & \multirow[t]{2}{*}{$3+$} & \multirow[t]{2}{*}{$4+$} \\
\hline & & & $\overline{M I}$ & Sev & Mi & Mod & Sev & & \\
\hline $\begin{array}{l}0.5 \\
0.5 \\
0.5 \\
0.5 \\
0.5 \\
0.5 \\
0.5 \\
0.5 \\
0.5 \\
0.5 \\
0.5\end{array}$ & $\begin{array}{c}6 \\
7 \\
8 \\
9 \\
10 \\
11 \\
12 \\
14 \\
15 \\
16 \\
18\end{array}$ & $\begin{array}{l}3 \\
3 \\
4 \\
3 \\
3 \\
2 \\
4 \\
3 \\
3 \\
1 \\
1\end{array}$ & $\begin{array}{l}1 \\
3 \\
4 \\
2 \\
2 \\
5 \\
3 \\
3 \\
\end{array}$ & 1 & & & . & & \\
\hline $\begin{array}{l}0.6 \\
0.6 \\
0.6 \\
0.6 \\
0.6\end{array}$ & $\begin{array}{l}14 \\
16 \\
18 \\
20 \\
22\end{array}$ & $\begin{array}{l}1 \\
2 \\
1\end{array}$ & $\begin{array}{l}3 \\
4 \\
6 \\
3 \\
6 \\
\end{array}$ & 2 & & & & & \\
\hline $\begin{array}{l}0.8 \\
0.8 \\
0.8 \\
0.8\end{array}$ & $\begin{array}{l}24 \\
26 \\
28 \\
30\end{array}$ & 3 & $\begin{array}{l}7 \\
6 \\
2 \\
1 \\
\end{array}$ & $\begin{array}{l}2 \\
4 \\
8 \\
2\end{array}$ & $\begin{array}{l}2 \\
2 \\
7 \\
7\end{array}$ & & & & \\
\hline $\begin{array}{l}1.0 \\
1.00 \\
1.0 \\
1.00\end{array}$ & $\begin{array}{l}30 \\
32.5 \\
35 \\
37.5\end{array}$ & & & $\begin{array}{l}4 \\
2\end{array}$ & $\begin{array}{l}2 \\
3 \\
1 \\
1\end{array}$ & $\begin{array}{l}1 \\
2 \\
1\end{array}$ & $\begin{array}{l}1 \\
2\end{array}$ & 1 & \\
\hline
\end{tabular}




\section{5}

TABLE 5

STATISTICAL EVAIJATION OF RESULTS

\begin{tabular}{|c|c|c|c|c|c|}
\hline Fabrie & System & $\begin{array}{l}\text { Time } \\
\text { (sec) }\end{array}$ & 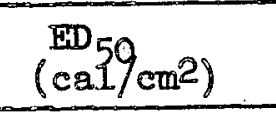 & $\begin{array}{l}\text { Confidence Interval } \\
\left(\text { cal } / \mathrm{cm}^{2}\right)\end{array}$ & $\begin{array}{l}\text { No. of } \\
\text { Exposure: }\end{array}$ \\
\hline$\frac{2 \text { Layers }}{\text { Contact }}$ & $\begin{array}{l}\text { Regular } \\
\text { HPM }\end{array}$ & 0.5 & $\begin{array}{l}7.3 \\
7: 4\end{array}$ & $\begin{array}{l}6.63-8.03 \\
6.98 \times 7: 84\end{array}$ & $\begin{array}{l}168 \\
165\end{array}$ \\
\hline $5 \mathrm{mep}$ & $\begin{array}{l}\text { Regular } \\
\text { HPM }\end{array}$ & $\begin{array}{l}0.5-1.0 \\
0.8-1.0\end{array}$ & (8.4 appros) & $\begin{array}{c}\text { (not statistically valid) } \\
28.2-34.1\end{array}$ & $\begin{array}{l}206 \\
156\end{array}$ \\
\hline$\frac{4 \text { Layers }}{\text { Contact }}$ & & 2.0 & 44.0 & $41.3-46.9$ & 168 \\
\hline$\frac{6 \text { Layers }}{\text { Contact }}$ & & $1.0-3.0$ & ( 108$)$ & (unknown) & 42 \\
\hline
\end{tabular}


1. Davis, $T_{0} P_{0}$, Krolak, $L_{0} J_{0}$, and Blakney, $R_{0} M_{0}$, "Studies of Flaøh Burn: The Carbon Are Source", University of Rochester Atomic Energy Project Report, UR-226 (1952).

2. Kingsley, Ho $D_{0}$, Hogg, $I_{0}$, Payne, $J_{0} T_{\circ}$, and Morton, $J_{0} H_{\circ}$, . "Studies in Prolonged Anestihesia in Swine and Dogs", University of Rochester Atomic Energy Project Report, UR-152: 65 (February 1950)。

3. Litcbrield, J。To, Jxo, and Wilcoson, $F_{0}$, "A Simplified Method of Evaluating Doøe-Effect Esperiments", J.Pharmacol。 \& Espex。Therapeut, 96:99 (1949).

4. Moxtox, $J_{0} H_{0}$, Kingsley, $H_{0} D_{0}$, and Pearse, $H_{0} E_{0}$, "Studies on Flash Burns: Threshold Burns", Surgery, Gynecology and Obstetrics, 94:317. (Mareh 1952)。

5. Mortion, J。 $\mathbb{H}_{0}$, Kingsley, $\mathrm{H}_{\circ} \mathrm{D}_{0}$, and Pearse, $\mathrm{H}_{0} \mathrm{E}_{0}$, "Stuales on Flash Burns: The Frotective Effects of Certain Fabrics", Surgery, Gynecology and Obstetrice, 94, 497-501 (April 1952).

6. Perking, J。 B. $_{0}$, Pearge, $H_{0} . E_{\circ}$, and Kingsley, H. Do, "Study of Radiant Energy Bums: Effects of Exposure Time and Intensity", Univergity of Rochester Atomic Energy Project Report, UR-217 (1952).

7. Sheline, $G_{0} E_{0}$, Alpen, $E_{0} L_{0}$, Kuhl, $P_{0} R_{0}$, and Ahokas, $A_{0}$, "Effects of High Intensity Radiant Energy on Skin", U.'S, Navai Radiological. Defense Report \#346 and \#347 (1952).

This study was carried out through the facilities of the University of ( Rochester Atonic Energy Project, and its expenses defrayed under a grant from the Quaxtermaster Corps, U.S.Army. 
17

PERCENT 2+ BURNS THRU 4 LAYERS

INNER LAYER IN CONTACT WITH SKIN
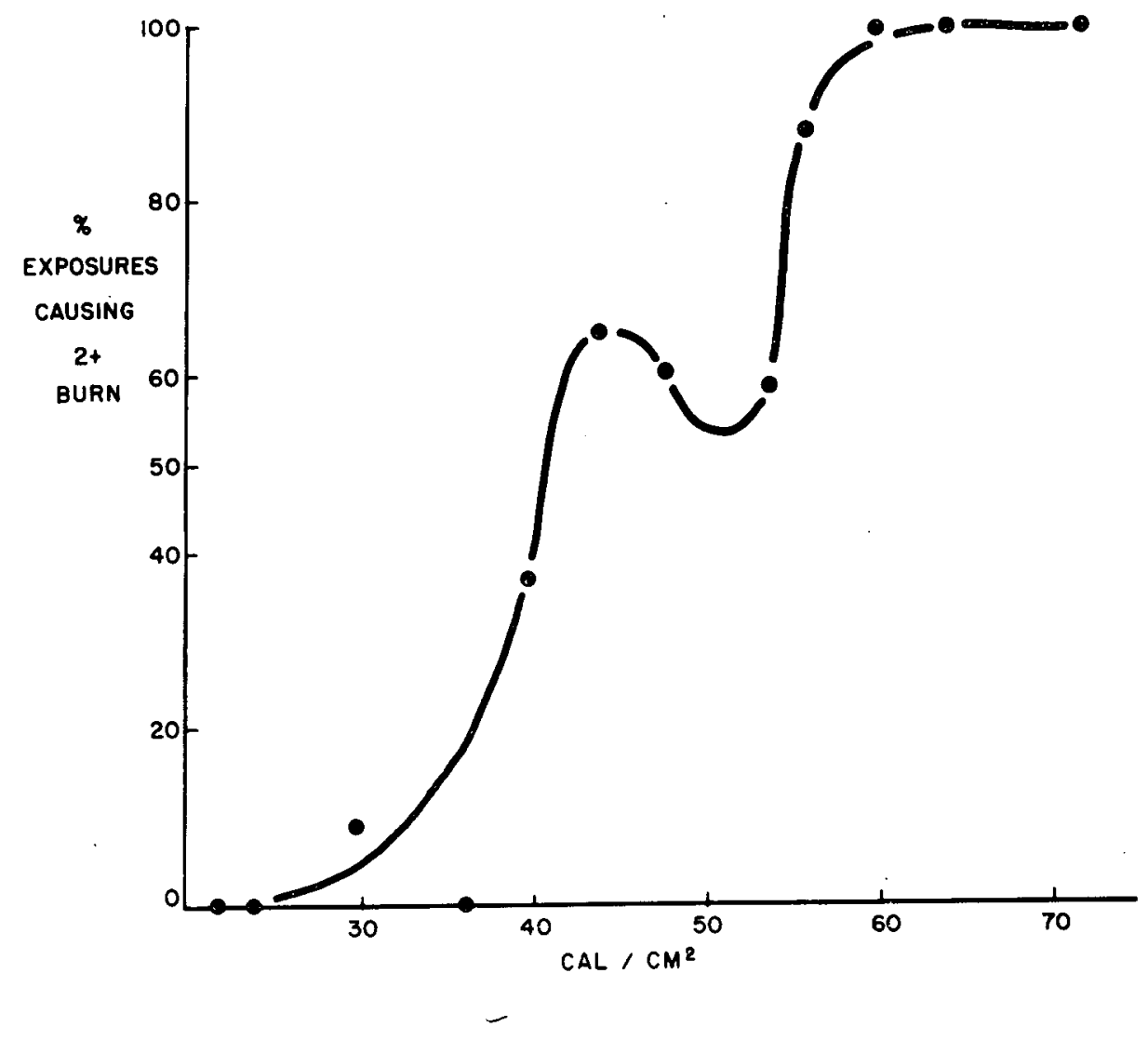

FIGURE I

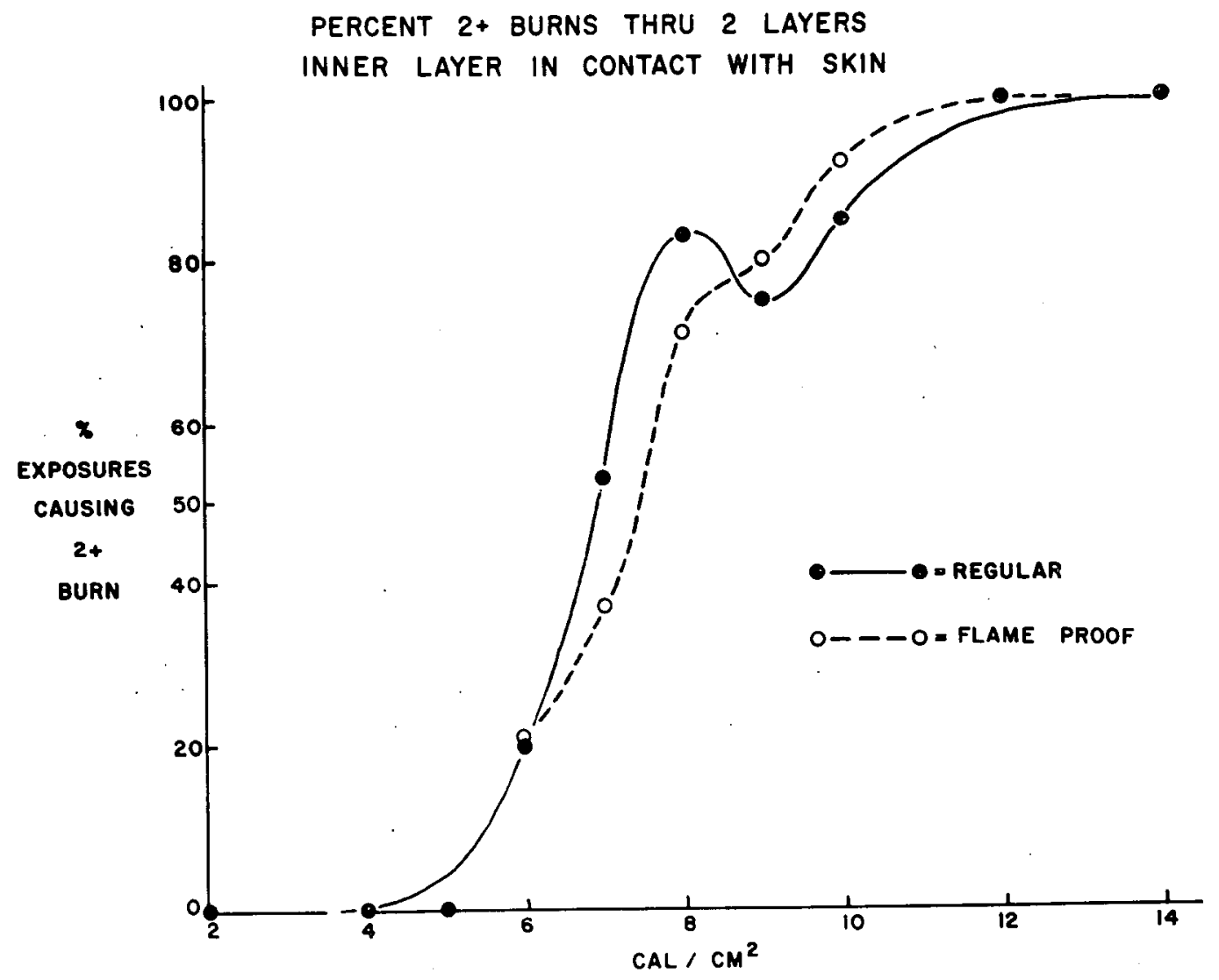

FIGURE 2 


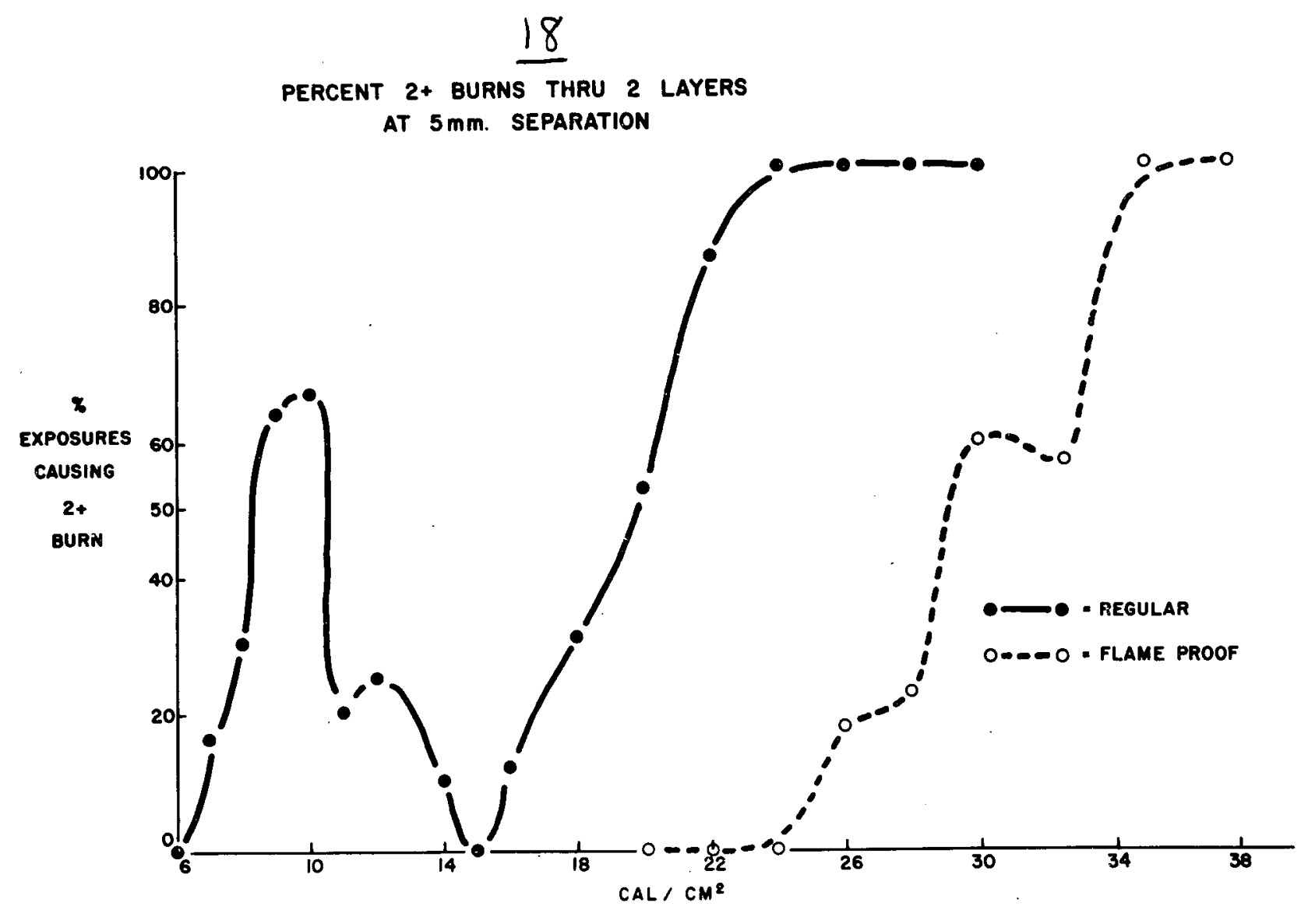

FIGURE 3

PERCENT $2+$ BURNS THRU 2 LAYERS

AT $5 \mathrm{~mm}$. SEPARATION

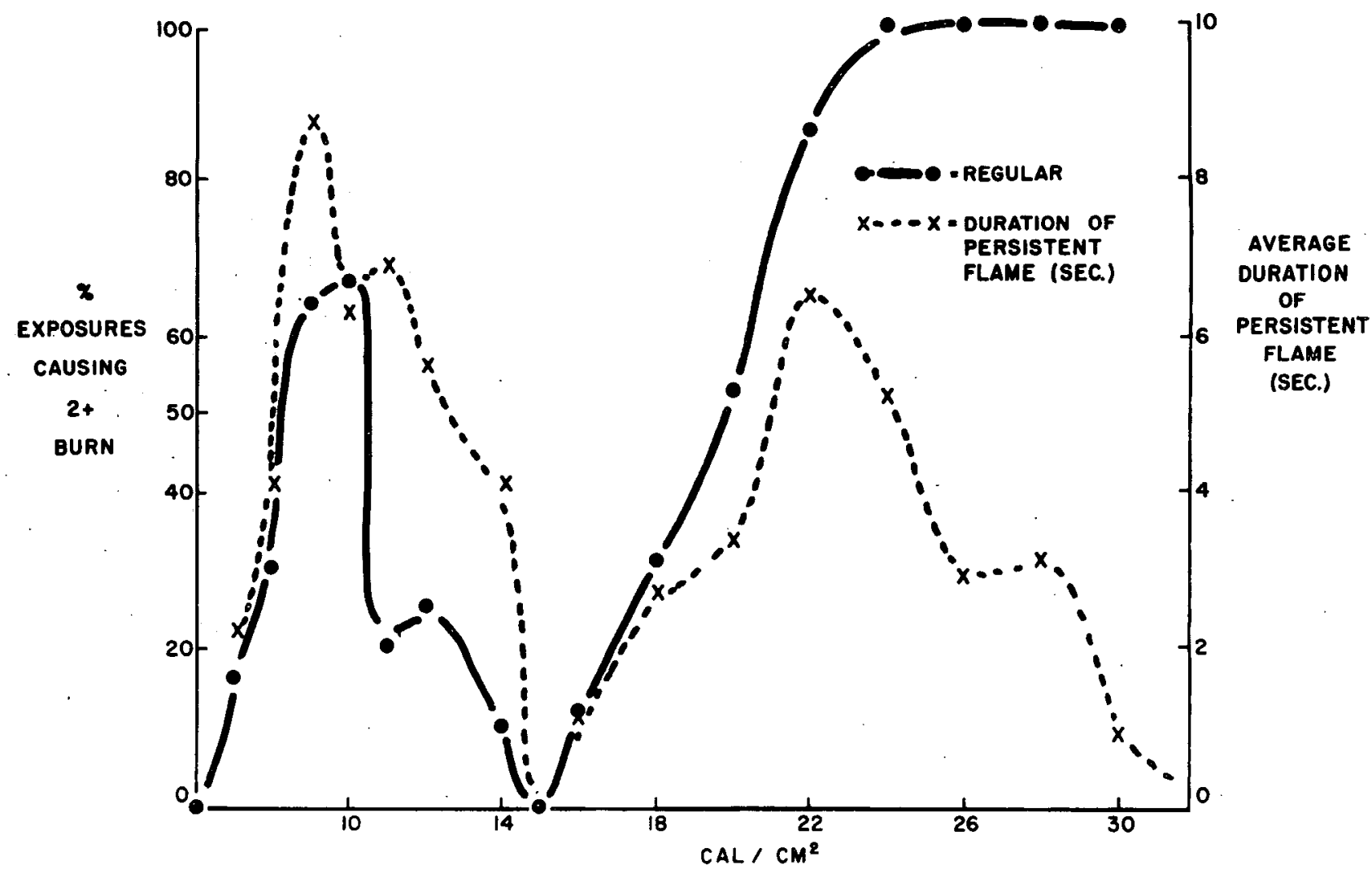

FIGURE 4 